\title{
LOP Game Development to Improve Early Childhood Mathematical-Logic Learning Ability
}

\author{
Epritha Kurnia Wati ${ }^{*}$, Widi Wulansari ${ }^{2}$ \\ 1,2 Department of Education, Early childhood education programs, Universitas Nusantara PGRI Kediri, Indonesia \\ e-mail: epritha@unpkediri.ac.id ${ }^{1}$, widiwulansari@unpkediri.ac.id ${ }^{2}$
}

\begin{abstract}
This study aims to develop a learning media product, namely the LoP Game to improve the Mathematical-Logic Learning Ability of Early Childhood Beginning. This type of research is a Research and Development (R\&D) using a model developed by Borg and Gall. There are 3 stages used in this study from 10 stages proposed by Borg and Gall. These stages include: research and information collecting, planning, and develop preliminary form of product. Data validity analysis was performed using the Aiken formula. The data is obtained from the results of the instrument assessment in the form of a questionnaire from material experts and media experts. The feasibility assessment is tested by 3 material experts and 3 media experts. From the results of the validity test, it can be seen that the expert judgment for the media in the LoP game is all valid with all aspects that have been previously described. Thus, it can be said that the LoP game is appropriate and suitable for the development of early childhood abilities, especially mathematical-logic abilities.
\end{abstract}

Keywords: LoP Game, Mathematical-Logic

\section{Introduction}

Early Childhood Education is education that is organized to facilitate the growth and development of the child as a whole or emphasizes the development of all aspects of the child's personality. According to Anggraini \& Priyanto (2019), early childhood education is education that is the starting gate for entering further education. Based on Mulyana, Nurzaman, \& Fauziyah (2017), early childhood development tasks must be experienced by every Early Childhood child in general. Therefore, PAUD provides opportunities for children to develop their personality and potential to the maximum, this is supported by opinions from Mufarizuddin (2017) that early childhood education is the provision of efforts to stimulate, guide, nurture and provide learning activities that will produce children's abilities and skills. So, it can be concluded that Early Childhood Education (ECE) is very important for the continued development of children's intelligence because the stimulation obtained in ECE will determine the child's future. This statement is in accordance with the opinion of Lestariningrum \& Handini (2017) which states that proper handling of children will affect the development of the next child. In the 2013 ECE curriculum, early childhood development aspects that must be developed include physical-motor, cognitive, language, artistic, social-emotional, and moral and religious values (Tatminingsih, 2019). On this basis, ECE institutions need to provide various aspects of development such as cognitive, language, social, emotional, physical and motoric. This is in accordance with the opinion of Nur, Hafina, \& Rusmana (2020) which revealed that the focus of early childhood early childhood development includes cognitive and physical-motor aspects. The scope of cognitive development consists of learning and problem solving, logical thinking, and symbolic thinking.

Early childhood is an individual who is undergoing a process of very rapid development and growth (Nirawati \& Yetti, 2019). Early Age is a period when individuals experience very rapid development. This period is so important that early age is often referred to as the golden age. At that time, children's brains developed rapidly (Novitasari, 2018). In line with this opinion, Nirawati \& Yetti (2019) revealed that early childhood is an individual who is undergoing a process of development and growth that is very rapid. As stated in Zahara, Khadijah, \& Lubis

\footnotetext{
${ }^{*}$ Corresponding author.

Received 04 September 2020; Accepted 05 January 2021; Available online 25 March 2021

(c) 2020 JPI. All Rights Reserved
}

Jurnal Pendidikan Indonesia (JPI) | 68 
(2019), early childhood themselves are those who have an age range between $0-8$ years. At this time the process of growth and development in various aspects is experiencing a rapid period in the range of development.

Of the many potentials possessed by early childhood that deserve attention, one of which is logical-mathematical abilities. This is because, logical-mathematical abilities teach and train children to think logically, and introduce numbers and calculations. Citrowati (2019), revealed that mathematical logical intelligence is an ability that can be mastered by a child in solving various problems it faces in everyday life. This relates to patterns, sequences, classifications, sizes, concepts, numbers, one-to-one correspondences, the concept of geometric shapes, estimating and processing data by manipulating and using concrete media before operating abstract symbols. The opinion regarding the notion of mathematical intelligence is in line with the opinion of Hanifah \& Alam (2019) which reveals that mathematical intelligence can be interpreted as logical intelligence and reasoning, which is the basis for problem solving by understanding the principles underlying cause and effect or manipulating numbers, quantities, and operations.

The problem that occurs today is that learning logical-mathematical intelligence is seen as a frightening specter for children. In fact, not a few children are reluctant to learn mathematical logic. In other words, most children avoid this intelligence because it is difficult and considered confusing to be learned and understood by children. This is proven by the lack of interest in logical-mathematical learning in various educational institutions in Indonesia. From the facts of the findings of field observations on learning activities to develop logicalmathematical abilities in several kindergartens in Kediri City, the problem that researchers found in the field is that there are still many children who have difficulty recognizing the symbols of numbers $1-20$, children have difficulty distinguishing numbers that are almost The form is the same, for example, between the numbers 6 and 9, the child has not been able to pronounce the sequence of numbers correctly, the child has difficulty connecting the symbol of numbers with objects up to 20 . These problems are caused because so far in the learning process the teacher only uses media that the child feels less interesting, such as through teacher verbal explanations, picture media, and children's worksheets, and teachers are also more likely to apply the learning model with paper and pencil. Based on Marli'ah (2019), the development of logic-mathematics skills by giving assignments using children's worksheets will give the impression of being stiff, unpleasant, and giving less opportunity for children to interact with concrete objects. This is not in accordance with the essence of ECE, namely playing while learning. In line with opinion Suryaningsih \& Rimpiati (2018) which reveals that the child's world is play, the child understands the world through the process of play. Trisniawati, Rahayu, \& Rhosyida (2018) also revealed that related to the characteristics of early childhood, students usually still like playing activities as the main part of learning. Menurut Dwiyanti, Khan, \& Kurniawati (2018) playing for children can provide joy and also make the learning process more developed. Also supported by the opinion of Aisyah, Iriyanto, Astuti, \& Yafie (2019), the teaching and learning process of early childhood which emphasizes the principles of learning while playing and playing while learning. Then obey Muloke, Ismanto, \& Bataha (2017), children's cognitive abilities can be demonstrated by carrying out play activities using game tools that contain elements or educational values.

Logical-mathematical learning is actually everywhere close to our daily lives. The passions for logical-mathematical must be raised from an early age, and learning logicalmathematical while playing will give early childhood the pleasure in knowing mathematics. Conforming to Setiawan (2018), learning that uses media in children's learning directs children to learn in a fun and easily accepted way in the context of children's understanding that is still simple. According to Anggara in (Widiana, Parera, \& Sukmana, 2019), learning media are anything that can be used to transmit messages or learning materials so that they can stimulate students' attention, interest, thoughts, and feelings of learning to achieve predetermined learning goals. While the function of learning media according to Suryani in (Widiana et al., 2019), namely "(1) supporting tools to create an effective teaching and learning situation), (2) part of the whole teaching and learning process, (3) helping to build abstract concepts into 
concrete so as to reduce verbalism in understanding, (4) reviving students' learning motivation, (5) improving the quality of teaching and learning".

One of the learning media that can be used for logical-mathematical learning is through educational games based on Power point. Educational games consist of two words, namely game and education. Game which comes from English which means game, is something that can be played with certain rules so that there are winners and losers, usually in the context of not being serious for entertainment purposes only, which includes games including things like action, adventurous action, simulation, construction and management, role playing games, strategy, racing, sports, puzzles and word games. Whereas education or education is a conscious and continuous effort carried out by the government, family and society for the purpose of changing an individual to be directed and better, in all aspects of his life. So that educational games are games designed or made to stimulate thinking, including increasing concentration and solving problems (Putra, Sanubari, \& Manggena, 2017). In line with this opinion Naimah, Winarni, \& Widiyawati (2019), argues that the educational game is one of the game media that contains the scope of learning material used to educate students in a fun learning process. Another opinion was conveyed by Fithri \& Setiawan (2017) revealed that games have positive functions and benefits for children, among them, children get to know computer technology, lessons to follow directions and rules, practice solving problems and logic, train motor nerves and spatial skills, establish communication between parents when playing together, and provide entertainment. Likewise according to Lestariningrum (2018) who said that Game is something that is active, moving, and not stagnant and limited by space and time. They can be applied at any time in an impulsive social and social context.

Based on previous research by Sari, Yetti, \& Hapidin (2020) has succeeded in proving that there is a significant change between before using Mipon's Daily game media and after using the media, in this study it was revealed that the use of Power Point-based learning media was effective for developing numeracy skills of children aged 5-6 years. The results of Prawiranegara (2019) succeeded in proving that the development of computer-based basic mathematics learning materials at Kindergarten at Bintaro Nature School proved effective in the effectiveness trials that had been implemented. The media developed can improve children's cognitive development, especially basic mathematics, as well as learning motivation, and learn to recognize numbers through computer-based mathematics learning.

Based on the fact that there is an imbalance in the learning process in early childhood education related to the development of logical-mathematical aspects of Early Childhood, many children experience difficulties when learning and get bored easily while studying, even though the logical-mathematical aspects of development are very important aspects to be developed so that children are ready. enter the next level of education. The current demand is for children to enter elementary school, they must be able to read, write and count. But in reality, most of the implementation of learning activities by teachers is considered boring because they only use old school media. This phenomenon is reinforced by several previous studies that have been stated previously, the researchers are trying to design educational games that are in accordance with the character of Early Childhood that can be used in logicalmathematical learning activities.

Researchers designed power point-based games, which are one type of computerassisted multimedia-based learning media. Computer-assisted learning media that uses Technology and Communication Science which is part of ICT are modified attractively by adding animated images, animated text, and sound so that learning is more fun (Nurlilawaty, Sri Milfayetti, 2018). Multimedia is the use of computers to present and combine text, sound, images, animation, audio, and video with tools and connections (links) so that users can navigate, interact, create and communicate (Hasmalena, Rukiyah, \& Rantina, 2018). Researchers developed this game because there was no interactive based educational game that contained mathematical logical development material, with varied material, in the previous interactive media development it only contained simple material. LoP game features, among others

This educational game contains learning to count activities, recognizing geometric shapes, colors, subtraction, addition, which is packaged in an attractive way, and does not 
make it difficult for children, namely "Logical of Mathematic Power" (LoP) Game. The LoP game is designed according to the child's development stage, namely in the preoperational stage, namely the concrete thinking stage. Children in this stage need concrete media to be able to assist children in achieving levels of learning achievement (Veronica, 2018).

One of the materials available in the LoP Game is the introduction of geometric shapes, geometry is the basis for mathematics and development. Besides being able to develop logical thinking skills, geometry is also effective in helping solve problems in many branches of mathematics (Hasanah \& Agung, 2019). The next material in the Lop Game is color recognition. The ability to recognize colors is one aspect of cognitive abilities because color recognition in children is a process for learning auditory, visual and memory where these three aspects are related to children's intellectual development. By recognizing colors, the child's brain senses will be stimulated (Nityanasari, 2020). The last menu of the LoP Game is about counting operations. According to Malapata \& Wijayaningsih (2019) the ability to count is one of the lessons taught in early childhood education as a determination in the Elementary School level. Referring to the various learning problems that have arisen, the support of previous research, and also various underlying theories, the purpose of carrying out this research is that it is hoped that through the development of the LoP game it can help to provide solutions to logical-mathematical learning constraints and the information obtained from this research can be a practical reference for subsequent research to develop similar learning strategies on a broader range of materials with other innovative game forms.

This study aims to develop a learning media product, namely the LoP Game to improve the Mathematical-Logic Learning Ability of Early Childhood Beginning.

\section{Method}

In terms of its objectives, this research is a development research using a model developed by Borg and Gall. Development stages according to Gall, Borg, \& Gall (2003), namely, as follows. a) needs analysis and data collection, b) planning stage, c) product design development, d) initial test (validation), e) initial product revision f) limited field trial, g) product revision, h) field test, i) improvement of the final product, j) dissemination and implementation (Saidah \& Damariswara, 2019). Adopting this development model, we use 3 stages used in this study. These stages include: (1) research and information collecting, (2) planning, dan (3) develop preliminary form of product. All the stages that have been described can be explained in Figure 1.

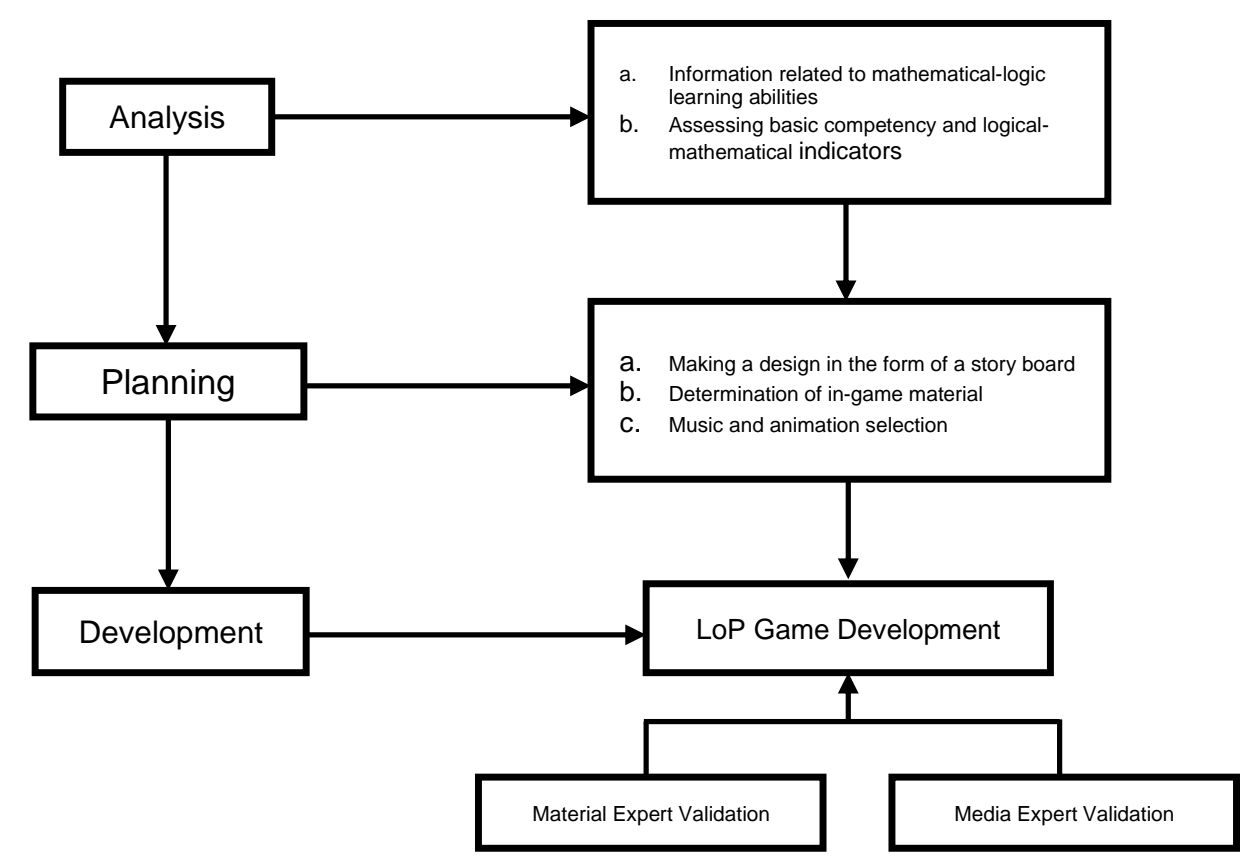

Figure 1. LoP Game Development Research Model 
Data validity analysis was performed using the Aiken formula. The data is obtained from the results of the instrument assessment in the form of a questionnaire from material experts and media experts.

\section{Result and Discussion}

\section{Results}

LoP “Logical of Mathematic Power" Game Development

The results of developing LoP game products can be seen in the following figure:

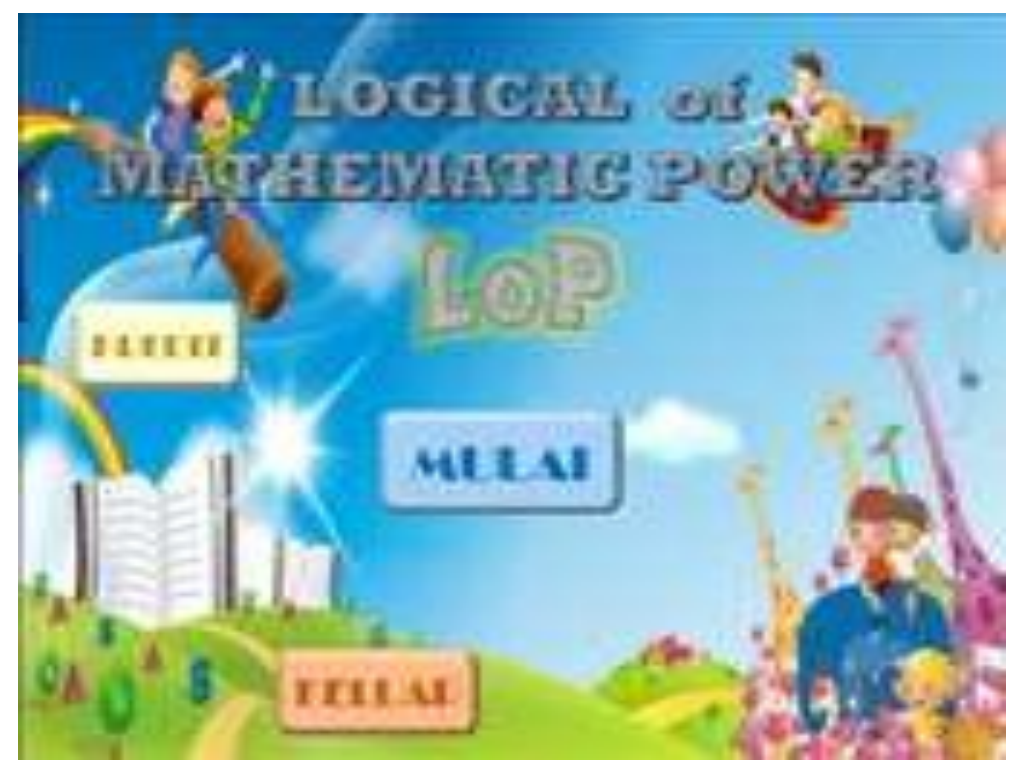

Picture 2. Initial Display

In the start screen there are buttons for starting the game, exiting the game, and services about developer data.

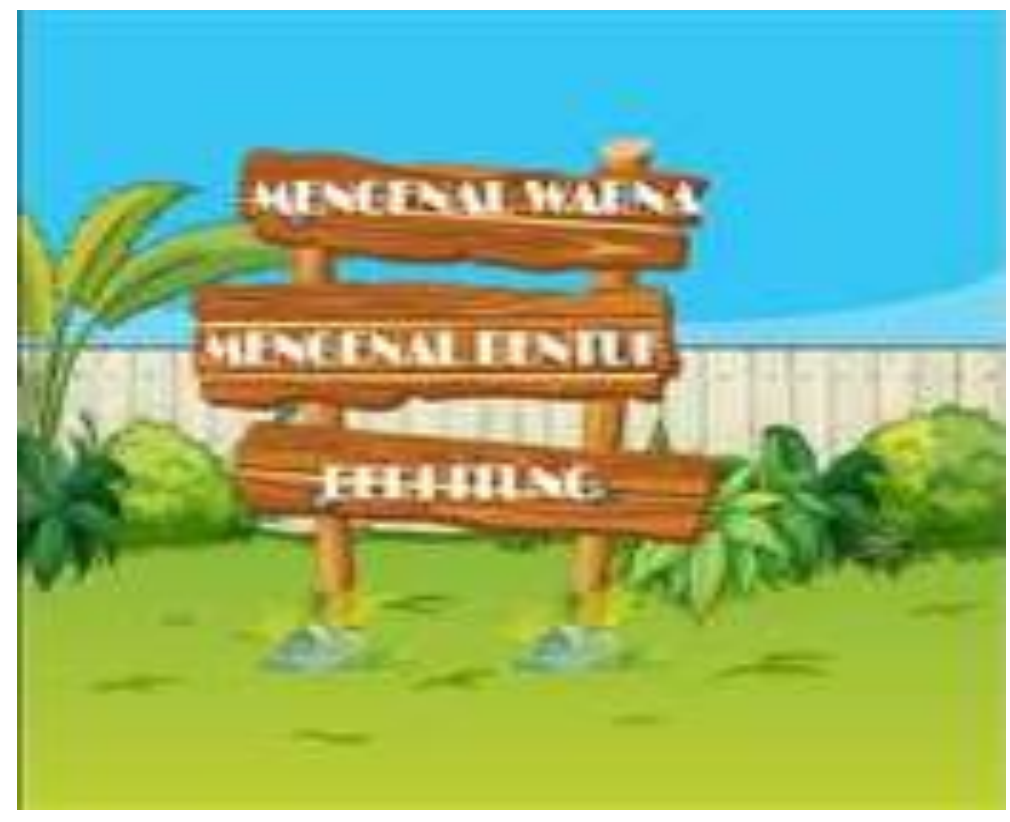

Picture 3. Main Course 
The main menu contains choices of material to be played. There are 3 materials presented, namely recognizing colors, recognizing shapes, and counting. Each material has 5 levels with increasing difficulty levels and different stories.

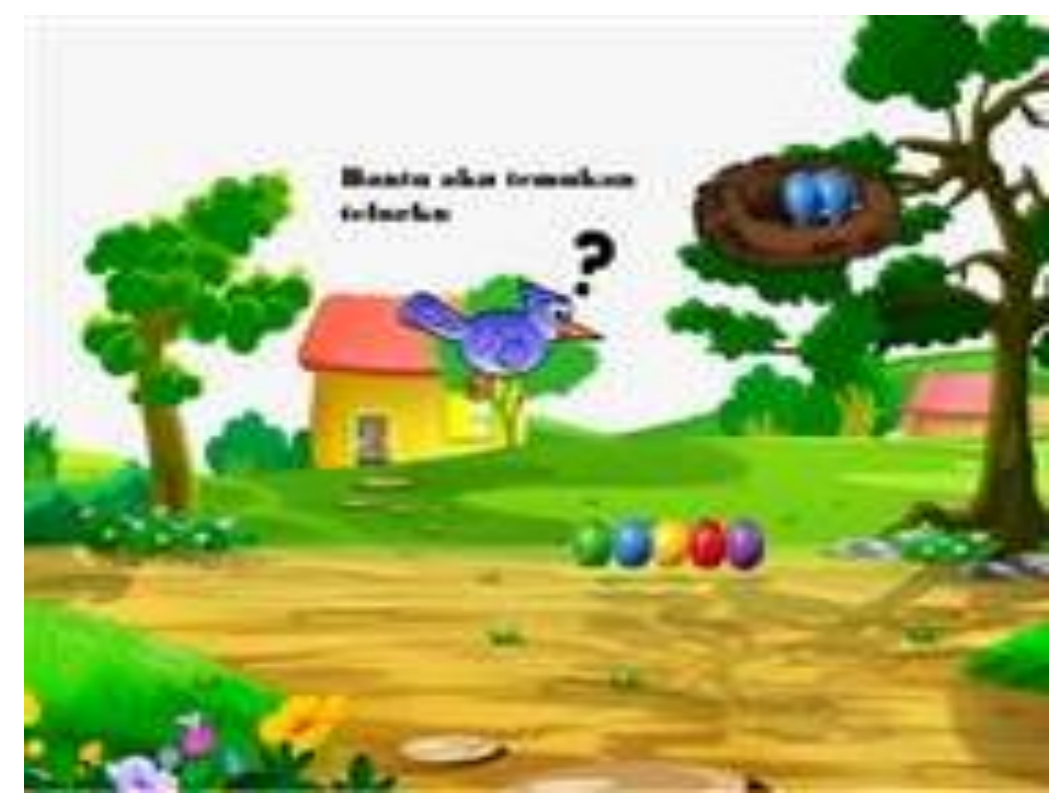

Picture 4. Level 1 Recognizing Color

At level 1 with the material to recognize colors, children are invited to help a blue bird find an egg that has fallen from the nest. If successful it will continue to the next level with the story and the level of difficulty increasing. However, if it is wrong then the player will return to the same level. Likewise, with the material recognizing form and counting, the same rules are applied in the two materials. Level 1 in material recognizing shapes, children are invited to find objects that match a white circle, while in counting material players are invited to count the number of cows belonging to the farmer. If players can complete 5 levels of each material, they will get a prize of 2 thumbs up appreciation from "Si Kuning". This display also contains buttons for returning to the home screen and main menu.

\section{Appropriateness LoP “Logical of Mathematic Power" Game Eligibility by Material Experts}

The assessment of the feasibility of the material was carried out by 3 experts, namely 1 from Lecturer in the Department of Early Childhood Education and 2 from Kindergarten teachers. The aspects assessed include: (1) suitability of the material, (2) attractiveness of presentation, (3) accuracy of language use, (4) ease of understanding of the material, (5) attractiveness of visualization, (6) interest in media, (7) ease of use, (8) learning effectiveness, (9) evaluation effectiveness, (10) appropriateness of evaluation tools. The following results from material expert validation are presented in Table 1.

Tabel 1. Material Experts Validation Results

\begin{tabular}{ccc}
\hline Item & V (Aiken Value) & Result \\
\hline Item 1 & 0,89 & Valid \\
Item 2 & 0,89 & Valid \\
Item 3 & 0,67 & Valid \\
Item 4 & 0,78 & Valid \\
Item 5 & 0,78 & Valid \\
Item 6 & 0,89 & Valid
\end{tabular}




\begin{tabular}{ccc}
\hline Item & V (Aiken Value) & Result \\
\hline Item 7 & 0,67 & Valid \\
Item 8 & 0,78 & Valid \\
Item 9 & 0,56 & Valid \\
Item 10 & 0,56 & Valid \\
\hline
\end{tabular}

Based on Table 1, it can be seen that expert ratings for the material in the LoP Game are all valid with all the aspects that have been previously described. Thus, it can be said that the material in the LoP game is suitable and suitable for the development of early childhood abilities, especially mathematical-logic abilities.

\section{Eligibility by Media Experts}

The media feasibility assessment was carried out by 3 experts, namely 1 from Lecturer of the Early Childhood Education Department and 2 from Kindergarten teachers. The aspects assessed include: (1) convenience with 4 question items, (2) attractiveness with 4 question items, (3) effectiveness with 2 question items, (4) accuracy / suitability with 3 question items. The following results from the media expert validation are presented in Table 2.

Tabel 2. Media Experts Validation Results

\begin{tabular}{ccc}
\hline Item & V (Aiken Value) & Result \\
\hline Item 1 & 0,89 & Valid \\
Item 2 & 0,78 & Valid \\
Item 3 & 0,89 & Valid \\
Item 4 & 0,78 & Valid \\
Item 5 & 0,78 & Valid \\
Item 6 & 0,67 & Valid \\
Item 7 & 0,89 & Valid \\
Item 8 & 0,89 & Valid \\
Item 9 & 0,78 & Valid \\
Item 10 & 0,78 & Valid \\
Butir 11 & 0,89 & Valid \\
Butir 12 & 0,89 & Valid \\
Butir 13 & 0,78 & Valid \\
\hline
\end{tabular}

Based on Table 2, it can be seen that expert assessments for media in the LoP game are all valid with all aspects that have been previously described. Thus, it can be said that the LoP Game is suitable and suitable for the development of early childhood abilities, especially mathematical-logic abilities.

\section{Discussion}

This development research was only carried out until the product validation stage, not yet at the trial stage. In this study using several steps in developing the "Logical of Mathematic Power" (LoP) Game. The initial steps taken in this research are Analysis: Analytical activities were carried out by conducting surveys to various kindergartens through interviews with kindergarten heads and class teachers. This interview was conducted with the aim of obtaining information related to situations and conditions as well as problems with children's logicalmathematical learning abilities, Planning: The planning stage begins with the creation of a game design and concept that is listed in the product draft. The game draft that has been made is then presented in a focus group discussion (FGD) with several material and media experts in the field of early childhood education. It is intended that the games to be made can function and be in accordance with the aspects of early childhood development. The implementation of the FGD resulted in the creation of a story board and material that became the content of the 
game. This game consists of 3 materials, including: (1) recognizing shapes, (2) counting, and (3) recognizing colors. Each level in this game has a different difficulty level, Development: The development stage is the development of the draft into a finished game. The finished games were then presented again in a focus group discussion (FGD) with several material and media experts in the field of early childhood education. Through FGD, the game will be validated before being tested on a small and large scale.

After carrying out the development process and going through the expert validation stage, it can be seen that the LoP Game is suitable for use. In addition, the LoP Game has several advantages compared to development products from other studies. Among them are research from Waziana \& Febriansyah (2016). Then research by Atiaturrahmaniah \& Ibrahim (2017). Next research from Hidayah, Wahyuni, \& Ani (2017), and further research by Windiartha (2017) entitled. In these studies the field trial process has been carried out and resulted in a product based on Adobe Flash software. Although the products developed from research that have been carried out by several previous researchers are declared suitable for widespread use, Adobe Flash-based media has drawbacks, namely in the application of Adobe Flash CS6 media in the learning process, sufficient preparation and special skills are required so that teachers must be able to choose an idea that is interesting enough to be poured into Adobe Flash (Mustarin, Arifyansah, \& Muh.Rais, 2019). This deficiency deserves attention because the majority of early childhood teachers do not master IT, this is supported by the results of research from Wulansari, Kurniawati, \& Dwiyanti (2017) which revealed that the results of the survey conducted in the professional and pedagogical competency sections indicated that there were still many abilities in mastering the concepts of Paudan, science and technology, and foreign languages, then in the provision of learning tools and resources, and class management which were classified as low so that it needed to be improved. Meanwhile, learning game products based on Power point have several advantages which were also expressed by several researchers, namely 1). PowerPoint media is equipped with pictures, text, and videos that attract students in learning. Thus it can support the teacher as a learning medium in the classroom (Wijayanti \& Relmasira, 2019), 2). Power point on the learning process has advantages including: a) The presentation is attractive because there are games of color, letters, and text animation and image animation, b) More stimulating students to find out more information about the teaching materials presented, c) Visual information messages are easy for students to understand, d) Teachers do not need to explain much of the teaching materials that are being presented, e) Can be reproduced as needed, and can be used repeatedly, f) Can be stored in the form of optical or magnetic data, making it practical to carry anywhere (Hamzah, 2019).

Power Point, which is a type of interactive multimedia, has many advantages compared to other media. This is in line with the opinion of Illahi, Sukartiningsih, \& Subroto (2018) that interactive multimedia is practically used in the learning process, it is hoped that the teacher can use it in the learning process and can be an inspiration for the manufacture of other learning media. Interactive multimedia is effectively used to improve students' critical thinking skills. This is in line with the opinion of Armansyah, Sulton, \& Sulthoni (2019), interactive multimedia is a learning facility independently without the assistance of a teacher. Interactive multimedia is flexible so that students can choose to study the material according to their wishes.

From the description above, it can be concluded that the LoP game is a game that is completely new and adapted to the learning needs of early childhood to make it easier for them to understand the material presented. This game is made with an attractive appearance and contains attractive colors to attract Early Childhood interest to play it. This game can be used as a learning medium for early childhood, with an attractive appearance and easy use that makes users very interested in using this game. The material presented is also in accordance with the needs of early childhood.

\section{Conclusions and Suggestions}

Based on the results of the analysis that has been obtained from the expert validity test, the following conclusions can be obtained: The assessment of the feasibility of the 
material was carried out by 3 experts, namely 1 Lecturer in the Department of Early Childhood Education and 2 Kindergarten teachers. The results of the material feasibility test obtained from 3 material experts are all valid in all aspects, and thus it can be said that the material in the LoP game is appropriate and suitable for use for the development of early childhood abilities, especially logical-mathematical abilities, and The media feasibility assessment was carried out by 3 experts, namely 1 lecturer of the Early Childhood Education Department and 2 Kindergarten teachers. The results of the media feasibility test obtained from 3 media experts are all valid in all aspects, and thus it can be said that the material in the LoP game is appropriate and suitable for use for the development of early childhood abilities, especially logical-mathematical abilities.

\section{References}

Aisyah, E. N., Iriyanto, T., Astuti, W., \& Yafie, E. (2019). Pengembangan Alat Permainan Ritatoon Tentang Binatang Peliharaan Sebagai Media Stimulasi Kemampuan Kognitif Anak Usia Dini. JKTP: Jurnal Kajian Teknologi Pendidikan, 2(3), 174-180. http://doi.org/10.17977/um038v2i32019p174.

Anggraini, V., \& Priyanto, A. (2019). Peningkatan Kemampuan Pengenalan Sejarah Budaya Minangkabau Melalui Lagu Kreasi Minangkabau bagi Anak Usia Dini. Kaganga: Jurnal Pendidikan Sejarah dan Riset Sosial Humaniora, 2(1), 1-9. https://doi.org/10.31539/kaganga.v2i1.703.

Armansyah, F., Sulton, \& Sulthoni. (2019). Multimedia Interaktif Sebagai Media Visualisasi Dasar-Dasar Animasi. JKTP: Jurnal Kajian Teknologi Pendidikan, 2(3), 224-229. http://doi.org/10.17977/um038v2i32019p224.

Atiaturrahmaniah, \& Ibrahim, D. S. M. (2017). Pengembangan Media Pembelajaran Berbasis Adobe Flash dengan Penerapan Teori Van Hiele. Jurnal Didika: Wahana IImiah Pendidikan Dasar, 1(1), 1-13. https://ejournal.hamzanwadi.ac.id/index.php/didika/article/view/659.

Citrowati, E. (2019). Penerapan Konsep Geometri dalam Mengembangkan Logika Matematika di TK Melati Kabupaten Pasaman Barat Tahun 2018. Jurnal Menara IImu, 13(4), 3540. https://doi.org/10.33559/mi.v13i4.1305.

Dwiyanti, L., Khan, R. I., \& Kurniawati, E. (2018). Development of Smart Adventure Games to Improve the Readiness of the Initial Ability of Reading, and Writing (CALIS) on Early Childhood. Jurnal Obsesi: Jurnal Pendidikan Anak Usia Dini, 2(2), 149-154. https://doi.org/10.31004/obsesi.v2i2.91.

Fithri, D. L., \& Setiawan, D. A. (2017). Analisa dan Perancangan Game Edukasi Sebagai Motivasi Belajar untuk Anak Usia Dini. Jurnal Simetris, 8(1), 225-230. https://doi.org/10.24176/simet.v8i1.959.

Gall, M. D., Borg, W. R., \& Gall, J. P. (2003). Educational Research (7th ed.). Pearson.

Hamzah, K. (2019). Efektifitas Penggunaan Media Powerpoint Topik Lingkaran Terhadap Motivasi, Aktivitas dan Hasil Belajar Matematika Siswa. PROXIMAL: Jurnal Penelitian Matematika dan Pendidikan Matematika, 2(2), 18-24. https://www.journal.uncp.ac.id/index.php/proximal/article/view/1214.

Hanifah, M., \& Alam, S. K. (2019). Pengaruh Kemampuan Berpikir Logis Matematis pada Anak Usia Dini dengan Menggunakan Media Pembelajaran Lotto di Kelompok B. Jurnal Ceria, 2(6), 302-308. http://doi.org/10.22460/ceria.v2i6.p302-308.

Hasanah, L., \& Agung, S. (2019). Kemampuan Pengenalan Geometri Melalui Kegiatan Bermain Balok Anak Usia 5-6 Tahun. Journal of Early Childhood Education, 1(2), 4552. https://doi.org/10.17509/jpa.v2i2.24538.

Hasmalena, Rukiyah, \& Rantina, M. (2018). Pengaruh Penggunaan Multimedia Terhadap Pemahaman Konsep pada Mata Kuliah Pengembangan Kognitif dan Kreatifitas Anak Usia Dini di UNSRI Palembang. Jurnal Obsesi: Jurnal Pendidikan Anak Usia Dini, 2(1), 85-93. https://doi.org/10.31004/obsesi.v2i1.11. 
Hidayah, S., Wahyuni, S., \& Ani, H. M. (2017). Penggunaan Media Pembelajaran Interaktif dengan Aplikasi Adobe Flash CS6 untuk Meningkatkan Motivasi Belajar pada Kompetensi Dasar Menganalisis Peran, Fungsi dan Manfaat Pajak (Studi Kasus Siswa Kelas XI IPS 1 MAN 1 Jember Semester Genap Tahun Ajaran 2016. Jurnal Pendidikan Ekonomi, 11(1), 117-123. https://doi.org/10.19184/jpe.v11i1.5012.

Illahi, T. A. R., Sukartiningsih, W., \& Subroto, W. T. (2018). Pengembangan Multimedia Interaktif pada Pembelajaran Materi Jenis-Jenis Pekerjaan untuk Meningkatkan Kemampuan Berpikir Kritis. Jurnal Review Pendidikan Dasar: Jurnal Kajian Pendidikan dan Hasil Penelitian, 4(3), 826-835. http://doi.org/10.26740/jrpd.v4n3.p826-835.

Lestariningrum, A. (2018). The Effects of Traditional Game 'Congklak' and Self-Confidence Towards Logical Mathematical Intelligence Of 5-6 Years Children. Jurnal Indria, 3(1), 13-22. http://repository.unpkediri.ac.id/id/eprint/2503.

Lestariningrum, A., \& Handini, M. C. (2017). Analisis Pengembangan Kecerdasan Logis Matematis Anak Usia 5-6 Tahun Menggunakan Permainan Tradisional. Jurnal Pendidikan Usia Dini, 11(2), 215-225. https://doi.org/10.21009/JPUD.112.

Malapata, E., \& Wijayaningsih, L. (2019). Meningkatkan Kemampuan Berhitung Anak Usia 45 Tahun Melalui Media Lumbung Hitung. Jurnal Obsesi: Jurnal Pendidikan Anak Usia Dini, 3(1), 283-293. https://doi.org/10.31004/obsesi.v3i1.183.

Marli'ah, S. (2019). Mengoptimalkan Kemampuan Logika Matematika Anak Usia Dini Melalui Permainan Sains. SELING: Jurnal Program Studi PGRA, 5(1), 39-53. https://doi.org/10.29062/seling.v5i1.361.

Mufarizuddin. (2017). Peningkatan Kecerdasaan Logika Matematika Anak Melalui Bermain Kartu Angka Kelompok B di TK Pembina Bangkinang Kota. Jurnal Obsesi: Jurnal Pendidikan Anak Usia Dini, 1(1), 62-71. https://doi.org/10.31004/obsesi.v1i1.32.

Muloke, I. C., Ismanto, A. Y., \& Bataha, Y. (2017). Pengaruh Alat Permainan Edukatif ( Puzzle) Terhadap Perkembangan Kognitif Anak Usia 5-6 Tahun di Desa Linawan Kecamatan Pinolosian Kabupaten Bolaang Mongondow Selatan. Jurnal Keperawatan, 5(1), 1-6. https://ejournal.unsrat.ac.id/index.php/jkp/article/view/14718.

Mulyana, E. H., Nurzaman, I., \& Fauziyah, N. A. (2017). Upaya Meningkatkan Kemampuan Anak Usia Dini Mengenal Warna. Jurnal PAUD Agapedia, 1(1), 76-91. https://doi.org/10.17509/jpa.v1i1.7170.

Mustarin, A., Arifyansah, R., \& Muh.Rais. (2019). Penerapan Media Pembelajaran Adobe Flash CS6 dalam Meningkatkan Hasil Belajar Siswa Kelas X ATPH pada Mata Pelajaran Alat dan Mesin Pertanian di SMKN 4 Jeneponto. Jurnal Pendidikan Teknologi Pertanian, 5(1), 1-8. https://ojs.unm.ac.id/ptp/article/view/8189.

Naimah, J., Winarni, D. S., \& Widiyawati, Y. (2019). Pengembangan Game Edukasi Science Adventure untuk Meningkatkan Keterampilan Pemecahan Masalah Siswa. Jurnal Pendidikan Sains Indonesia, 7(2), 91-100. https://doi.org/10.24815/jpsi.v7i2.14462.

Nirawati, T., \& Yetti, R. (2019). Peningkatan Kemampuan Berhitung Anak Melalui Permainan Meja Putar di Taman Kanak - Kanak. Jurnal Riset Tindakan Indonesia, 4(1), 51-58. https://doi.org/10.29210/300338700.

Nityanasari, D. (2020). Alat Permainan Edukatif Pasak Warna untuk Meningkatkan Kemampuan Mengenal Warna pada Anak Usia Dini. Yaa Bunayya: Jurnal Pendidikan Anak Usia Dini, 4197(1), 9-13. https://doi.org/10.24853/yby.4.1.9-14.

Novitasari, Y. (2018). Analisis Permasalahan "Perkembangan Kognitif Anak Usia Dini ". PAUD Lectura: Jurnal Pendidikan Anak Usia Dini, 2(1), 82-90. https://doi.org/10.31849/paudlectura.v2i01.2007.

Nur, L., Hafina, A., \& Rusmana, N. (2020). Kemampuan Kognitif Anak Usia Dini dalam Pembelajaran Akuatik. Scholaria: Jurnal Pendidikan dan Kebudayaan, 10(1), 42-50. https://doi.org/10.24246/j.js.2020.v10.i1.p42-50.

Nurlilawaty, Sri Milfayetti, A. Y. (2018). Pengaruh Bermain Puzzle Berbasis ICT Terhadap 
Motivasi Belajar dan Kemampuan Membaca Permulaan Anak Usia 5-6 Tahun. Jurnal Tematik, 8(3), 264-273. https://doi.org/10.24114/jt.v8i3.12627.

Prawiranegara, H. (2019). Pengembangan Bahan Pembelajaran Pengenalan Matematika Dasar Berbasis Komputer bagi Anak Usia Dini. Jurnal IImiah Visi PGTK PAUD dan Dikmas, 14(1), 67-74. http://doi.org/JIV.1401.8.

Putra, K. P., Sanubari, T. P. E., \& Manggena, T. F. (2017). Pengaruh Intensitas Bermain Game Terhadap Tingkat Kognitif (Kecerdasan Logika-Matematika) Usia 8-9 Tahun. Jurnal Satya Widya, 33(2), 146-153. https://doi.org/10.24246/j.sw.2017.v33.i2.p146-153.

Saidah, K., \& Damariswara, R. (2019). Pengembangan Bahan Ajar Materi Dongeng Berbasis Kearifan Lokal Jawa Timur bagi Siswa Kelas III SD. Premiere Educandum: Jurnal Pendidikan Dasar dan Pembelajaran, 9(1), 73-81. https://doi.org/10.25273/pe.v9i1.4320.

Sari, N. M., Yetti, E., \& Hapidin. (2020). Pengembangan Media Permainan Mipon's Daily untuk Meningkatkan Kemampuan Berhitung Anak. Jurnal Obsesi: Jurnal Pendidikan Anak Usia Dini, 4(2), 831-839. https://doi.org/10.31004/obsesi.v4i2.428.

Setiawan, A. (2018). Meningkatkan Kemampuan Berhitung Anak Usia Dini Melalui Media Pembelajaran Matematika di RA Ma'arif 1 Kota Metro. SELING: Jurnal Program Studi PGRA, 4(2), 181-188. https://doi.org/10.29062/seling.v4i2.309.

Suryaningsih, N. M. A., \& Rimpiati, N. L. (2018). Implementation of Game-Based Thematic Science Approach in Developing Early Childhood Cognitive Capabilities. Jurnal Obsesi: Jurnal Pendidikan Anak Usia Dini, 2(2), 194-201. https://doi.org/10.31004/obsesi.v2i2.90.

Tatminingsih, S. (2019). Alternative Stimulasi Kemampuan Kognitif melalui Penerapan Model Pembelajaran Berbasis Permainan Komprehensif. Jurnal Obsesi: Jurnal Pendidikan Anak Usia Dini, 3(1), 183-190. https://doi.org/10.31004/obsesi.v3i1.130.

Trisniawati, Rahayu, A., \& Rhosyida, N. (2018). Implementasi Pembelajaran Origamasains Matematika dan Sains Sejak Dini. Jurnal IImiah Visi PGTK PAUD dan Dikmas, 13(2), 91-99. https://doi.org/10.21009/JIV.1302.3.

Veronica, N. (2018). Permainan Edukatif dan Perkembangan Kognitif Anak Usia Dini. PEDAGOGI: Jurnal Anak Usia Dini dan Pendidikan Anak Usia Dini, 4(2), 49-55. http://dx.doi.org/10.30651/pedagogi.v4i2.1939.

Waziana, W., \& Febriansyah. (2016). Pengembangan Media Pembelajaram Game Quiz untuk Anak-Anak Usia Dini Menggunakan Aplikasi Adobe Flash. Jurnal Manajemen Pendidikan Islam Al-Idarah, 1(1), 26-31. https://ejurnalstitpringsewu.ac.id/index.php/JMPl/article/view/5.

Widiana, I. W., Parera, N. P. G., \& Sukmana, A. I. W. I. Y. (2019). Media Permainan Ular Tangga untuk Meningkatkan Hasil Belajar Siswa Kelas IV pada Kompetensi Pengetahuan IPA. Journal of Education Technology, 3(4), 315-322. http://dx.doi.org/10.23887/jet.v3i4.22556.

Wijayanti, W., \& Relmasira, S. C. (2019). Pengembangan Media PowerPoint IPA untuk Siswa Kelas IV SD Negeri Samirono. Jurnal Penelitian dan Pengembangan Pendidikan, 3(2), 77-83. http://dx.doi.org/10.23887/jppp.v3i2.17381.

Windiartha, A. (2017). Pengembangan Media Berbasis Adobe Flash Player Latihan Teknik Dasar Futsal. Jurnal Olahraga Prestasi, 13, 68-88. http://pasca.um.ac.id/conferences/index.php/por/article/view/664.

Wulansari, W., Kurniawati, E., \& Dwiyanti, L. (2017). Evaluasi Kompetensi Lulusan Program Studi Pendidikan Guru Pendidikan Anak Usia Dini Universitas Nusantara PGRI Kediri. Jurnal Realita, 15(1), 1-12. https://doi.org/10.30762/realita.v15i1.464.

Zahara, R., Khadijah, \& Lubis, R. (2019). Upaya Meningkatkan Kemampuan Kognitif Melalui Penerapan Metode Pembelajaran Mind Mapping pada Anak Usia 5-6 Tahun di RA AlKamal. Jurnal Raudhah, 07(01), 26-39. http://dx.doi.org/10.30829/raudhah.v7i1.466. 